\title{
Menjadi Juru Kunci Islam Nusantara: Peran Perpustakaan dalam Melestarikan Naskah Islam Nusantara ${ }^{1}$
}

\author{
Parhan Hidayat $^{2}$
}

\begin{abstract}
Abstrak
Indonesia adalah negara dengan komunitas Muslim terbanyak di dunia. Corak keislaman di Indonesia juga memilik kekhasan tersendiri, yang berbeda dengan sumber aslinya di Timur Tengah. Salah satu cara memahami corak keislaman Indonesia adalah dengan mempelajari naskah-naskah Islam Nusantara yang tersebar di Indonesa, sampai ke negara-negara tetangga. Keberadaan naskah itu tentu menjadi kekayaan tak ternilai untuk bangsa kita, sehingga sangat perlu untuk dilestarikan. Perpustakaan sebagai lembaga yang berfungsi untuk mengumpulkan, mengelola, dan menyebarkan informasi, perannya dalam pelestarian naskah Islam Nusantara sudah pasti sangat diperlukan. Perpustakaan bahkan dapat menjadikan kekayaan naskah Islam Nusantara tersebut sebagai strategi branding untuk bersaing dengan perpustakaan lainnya. Selain mengumpulkan informasi tentang naskah, mengolah dan menyebarkan informasi tentang naskah Islam Nusantara, perpustakaan juga harus memiliki pustakawan-pustakawan yang handal dan mumpuni dalam melestarikan naskah Islam Nusantara. Keberadaan Database Sumber Primer Islam Nusantara yang nantinya akan diintegrasikan dengan sistem otomasi di perpustakaan Fakultas Adab dan Humaniora (FAH) UIN Jakarta, akan menjadikan perpustakaan FAH sebagai perpustakaan yang memiliki distingsi dan keunggulan tersendiri dibanding perpustakaan lainnya.
\end{abstract}

Kata Kunci: Perpustakaan; Naskah Islam Nusantara; Sumber Primer Islam Nusantara.

\begin{abstract}
Indonesia is the country with the largest Muslim community in the world. Islamic pattern in Indonesia also picks its own peculiarities, which is different from the original source in the Middle East. One way to understand the Indonesian Islamic style is by studying Islamic texts of archipelago scattered Indonesa, even to neighboring countries. The existence of the manuscript that will become invaluable wealth for our nation needs to be preserved. The library as an institution whose function is to collect, manage, and disseminate information, its role in the preservation of Islamic manuscripts archipelago is definitely indispensable. Libraries can even make the wealth of the archipelago of Islamic texts as a branding strategy to compete with other libraries. In addition to collecting information about the script, process and disseminate information on Islam Nusantara manuscripts, the library must also have librarians who are reliable and qualified in preserving texts of Islam Nusantara. The existenceof primary source databases of Islam Nusantara which will be integrated into the automation system in the library of the Faculty of Adab and Humanities (FAH) UIN Jakarta, will make FAH library as a library that has its own distinctions and advantages compared to other libraries.
\end{abstract}

Keywords: Library; Manuscripts of Islam Nusantara; Primary Sources of Islam Nusantara

\footnotetext{
${ }^{1}$ Disampaikan pada acara The First International Conference on Islam Nusantara, dengan tema, Islam Nusantara: Past and Present, Auditorium Harun Nasution, Rabu 24 September 2014.

2 Ilmu Perpustakaan, Fakultas adab dan Humaniora UIN Syarif Hidayatullah Jakarta.
} 


\section{A. Pendahuluan}

Siapa yang tidak kenal dengan Mbah Maridjan. Sosok sederhana penuh dedikasi ini akan dikenang orang karena komitmen pada tugas yang diberikan kepadanya. Mbah Maridjan adalah juru kunci Gunung Merapi yang rela menghembuskan nafas terakhirnya dalam menjalankan tugas. Beliau meninggal dalam keadaan bersujud di antara debu vulkanik dan puing-puing rumahnya, ketika Gunung Merapi kembali meletus pada tahun 2010 silam. Semasa hidupnya, sebagai juru kunci, setiap kali orang yang akan berkunjung ke Gunung Merapi pasti akan meminta izin dan nasehat beliau tentang tata krama, tata cara dan petunjuk saat berada di gunung tersebut. Beliau adalah rujukan utama bagi para pendaki gunung, pecinta alam atau bahkan peneliti yang akan mempelajari Gunung Merapi.

Perpustakaan, dalam konteks pelayanan paripurna, sebenarnya hampir memiliki fungsi yang hampir sama dengan legenda Gunung Merapi tersebut. Bedanya, bila Mbah Maridjan memberikan layanan informasi yang bersifat tradisional dan mistik, maka perpustakaan tugasnya adalah memberikan layanan komprehensif seputar kebutuhan informasi dalam suatu bidang ilmu tertentu.

Seperti halnya gunung Merapi (dan gunung-gunung lain di Indonesia yang membentuk ring of fire) yang menarik untuk diteliti dan diobservsi, maka begitu juga dengan khazanah budaya dan keberagamaan negara kita. Bumi pertiwi kita, Indonesia, memiliki ketertarikan tersendiri bagi para peneliti untuk dikaji lebih dalam, terutama dalam konteks keunikan Islam dan tradisi keislaman yang ada di dalamnya. Islam Indonesia memiliki tipikal pembeda dengan Islam di Timur Tengah. Bila di Timur Tengah masih kebingungan bagaimana cara mengakurkan Islam dan negara, maka di
Indonesia hal itu sudah lama selesai setelah para ulama turut berpartisipasi menyusun naskah pembukaan UUD Negara Republik Indonesia. ${ }^{3}$ Bahkan uniknya lagi, Islam yang datang untuk pertama kali ke Indonesia adalah Islam yang bercorak sufistik yang dipelopori oleh para wali. Islam yang dibawa para wali itu adalah Islam yang sangat toleran dengan budaya lokal, bukan Islam yang menggurui dan membid'ahkan segala sesuatu yang mungkin saja masih memiliki nilai kebaikan di dalamnya.

Menguatkan hal ini, Masdar Hilmy dalam salah satu artikelnya menyampaikan bahwa Islam Indonesia dapat menjadi alternatif dan trendsetter bagi komunitas muslim dunia. Hal ini sangat memungkinkan karena muslim di Indonesia memiliki tiga modal penting untuk mewujudkan hal tersebut. ${ }^{4}$ Pertama, sebanyak 204 juta Muslim dilahirkan dan tinggal di negeri ini. Mereka membentuk 12,5 persen dari seluruh jumlah kaum muslimin di dunia. Hal ini merupakan angka yang cukup signifikan untuk menggerakan arah baru peradaban Islam dunia.

Kedua, Islam Indonesia juga telah secara nyata melahirkan modus keberagamaan yang moderat, damai, toleran, terbuka dan ramah lingkungan. Memang di sanasini masih ditemukan letupan-letupan konflik dan perlawanan bawah tanah, tetapi jumlahnya tentu sangat kecil bila dibandingkan dengan aspirasi mayoritas umat Islam di negeri ini. Hal ini tentu jauh berbeda dengan wajah Islam di belahan dunia lain, misalnya di Timur Tengah. Di sana, hampir tiada hari yang tanpa diwarnai konflik dan kekerasan

\footnotetext{
3 Pernyataan ini disampaikan oleh Amin Abdullah dalam acara halal bihalal tahun 2014 di Auditorium Prof. Harun Nasution, UIN Syarif Hidayatullah Jakarta.

4 Masdar Hilmy. "Menjadi Islam Indonesia". Artikel dimuat pada harian Kompas pada tanggal 24 November 2012.
} 
berdarah. Sebuah kenyataan pahit, yang mudah-mudahan tidak menular terjadi ke negeri ini.

Ketiga, adalah tradisi kesarjanaan pernah membentuk diskursus keislaman tingkat dunia. Islam di negeri ini pernah melahirkan ulama berkaliber internasional, seperti Imam Nawawi alBantani dan Mahfud al-Trimisi, yang karya-karya tulisnya sempat beredar di belahan dunia lain, seperti kawasan Asia Tenggara dan Asia Selatan. Kekayaan Islam Indonesia ini juga pernah membidani lahirnya agamawan dan ilmuwan kontemperor seperti Nurcholis Madjid (Cak Nur) dan Abdurrahman Wahid (Gus Dur).

Selanjutnya Hilmy juga menyatakan bahwa antara Islam Indonesia (yang sering dianggap sebagai komunitas Islam pinggir) dan Timur Tengah (yang sering dianggap sebagai pusat munculnya Islam) yang memiliki rentang jarak yang sangat jauh, ternyata tidak berdampak pada terjadinya degradasi dan devaluasi kualitas keberagamaan Islam Indonesia. Sebaliknya, kejauhan jarak tersebut malah menjadi semacam blessing in disguise, yang memungkinkan Islam Indonesia meruangkan artikulasi dan eksperimentasi keberagamaan secara kreatif dan produktif untuk menghasilkan teladan keberagamaan alternatif yang lebih progressif, transformatif, dan kontekstual. $^{5}$

Hal ini tentu saja terjadi karena adanya teknik-teknis syiar Islam brilian yang dipelopori oleh para wali. Melalui gaya dakwah para wali, maka terbentuklah tipikal Islam baru yang terbukti dapat menyatu dan bersentuhan secara lembut dengan unsur budaya lokal. Hasilnya, Islam dapat mewujud dan mengintisari dalam diri seluruh pemeluk Islam di Indonesia tanpa harus menggerus inti keislaman dan tak perlu memusnahkan

\footnotetext{
${ }^{5}$ Masdar Hilmy, Menjadi Islam Indonesia.
}

jati diri pemeluknya sebagai orang Jawa, Sunda, Batak, Banjar atau identitas suku manapun.

\section{B. Pembahasan}

\section{Khazanah Intelektual Islam Indonesia}

Sudah tidak dapat dipungkiri lagi bahwa bumi pertiwi Indonesia telah melahirkan banyak ulama. Para ulama tersebut juga telah banyak menghasilkan karya-karya tulis yang berpengaruh. Karya-karya tersebut tidak saja dibaca dan dikaji oleh orang Indonesia sendiri tetapi telah tersebar hampir ke seluruh pelosok Asia Tenggara. Beberapa nama ulama Indonesia bahkan terkenal namanya di dunia. Mereka pada umumnya berguru di Kota Mekkah dan Madinah. Sebagian ada yang bermukim dan mengajar di dua kota tersebut, dan sebagian lagi pulang ke Indonesia. Contohnya adalah Syeikh Muhammad Arsyad al-Banjari. Nama beliau tidak hanya dikenal di Indonesia tapi juga kaum muslimin di Filipina, Turki, Arab Saudi, Mesir, dan India. Salah satu karya beliau yang terkenal adalah Sabilal Muhtadin. ${ }^{6}$

Ulama berikutnya adalah Syeikh Sulaiman Ar-Rasuli Al-Minangkabawi. Beliau seangkatan dengan Hasyim Asyhari, pendiri Nahdlatul Ulama. Pada tahun 1928, beliau bersama Syeikh Abbas Ladang Lawas dan Syeikh Muhammad Jamil Jaho menggagas berdirinya Persatuan Tarbiyah Islamiyah (Perti). Selain, itu ada nama Ulama Syeikh Sayyid Utsman Betawi, Syeikh Muhammad Khalil Al-Maduri, Syeikh Nawawi Al-Bantani, Syeikh Muhammad Mukhtar Al-Bagawi, dan Syeikh Abdul Hamid Asahan, serta ulama-ulama lain yang cukup banyak jumlahnya. ${ }^{7}$ Dari aktivitas mereka dalam menyebarkan

\footnotetext{
${ }^{6}$ Artikel diakses di situs Hidayatullah.com, dengan judul: "Ulama-ulama Indonesia yang Sudah Mendunia", artikel diakses pada tanggal 08 September 2014.

7 Ulama-ulama Indonesia yang Mendunia. Hidayatullah.com
} 
ilmu itulah terlahir banyak karya-karya dan naskah-naskah yang masih dapat ditemukan sampai sekarang.

\section{Manuskrip Sebagai Sumber primer Islam Nusantara}

Salah satu cara untuk membaca pola keberagamaan Islam di Indonesia bisa juga ditelaah lewat naskah-naskah Nusantara yang jumlahnya mencapai ribuaan naskah. Naskah dapat dipahami sebagai karangan yang masih ditulis oleh tangan, atau bisa juga diartikan sebagai karangan seseorang yang belum pernah diterbitkan. ${ }^{8}$

Menurut pakar naskah Islam Nusantara, Professor Oman Fathurahman, Manuskrip-manuskrip kita menggambarkan sebuah proses pribumisasi Islam pada masa lalu, mempertontonkan proses adaptasi teksteks Arab atau Parsi menjadi teks-teks lokal, serta terkadang membuktikan adanya proses peralihan atau perubahan ide dari sumber aslinya. ${ }^{9}$ Lebih lanjut, Fathurrahman menyampaikan bahwa melakukan pengkajian terhadap manuskrip-manuskrip Islam Nusantara mempunyai beberapa keuntungan strategis. ${ }^{10}$ Pertama, dapat menggali kekhasan serta dinamika Islam dan masyarakat Muslim lokal, karena manuskrip Islam Nusantara, selain menggunakan bahasa Arab, ditulis dalam

\footnotetext{
${ }^{8}$ Kamus Besar Bahasa Indonesia (KBBI)

9 Pertanyaan beliau ini disampaikan dalam acara Abdurrahman Wahid Memorial Lecture (AWML), seperti dimuat dalam berita www.gusdur.net, tanggal 21 Mei 2010, diakses penulis pada tanggal 05 September 2014.

10 Pernyataan ini disampaikan Oman Fathurrahman dalam makalah berjudul: "Penguatan Kajian Islam Nusantara" dalam acara saresehan Lakpesdam PCINU, Kairo Mesir, kamis 21 juli 2011. Penulis mengakses makalah ini di situs, http://oman.uinjkt.ac.id, tanggal 05 September 2014.
}

berbagai bahasa lokal seperti Aceh, Bali, Batak, Belanda, Bugis-Makasar-Mandar, Jawa dan Jawa-Kuna, Madura, Melayu, Minangkabau, Sansekerta, Sasak, Sunda, dan bahasa daerah lainnya. Sehingga mengkaji manuskrip Islam Nusantara berarti sama dengan menempuh short cut atau jalan pintas untuk mengetahui polapola hasil interaksi dan pertemuan Islam dengan budaya-budaya lokal Nusantara, yang tentunya menjadi kekayaan intelektual sendiri.

Kedua, kajian atas manuskrip-manuskrip Islam Nusantara dengan sendirinya akan menjadi menjadi bagian dari upaya untuk melestarikan cagar budaya Indonesia demi menjaga kemajemukan, kebangsaan, dan menjamin keberlangsungan transmisi pengetahuan yang telah diwariskan sejak ratusan tahun lalu.

Ketiga, keberhasilan memetakan kejayaan tradisi Islam Nusantara pada gilirannya dapat menunjukan kepada dunia internasional bahwa Nusantara bukanlah wilayah pinggiran, melainkan bagian tak terpisahkan dari dunia Islam secara keseluruhan.

Dengan demikian naskah-naskah Islam Nusantara merupakan kekayaan intelektual yang harus dilestarikan oleh seluruh anak bangsa. Hal ini adalah suatu keharusan, karena banyak juga di antara naskah-naskah itu merupakan karyakarya "yang pertama". Seperti tafsir Melayu pertama, Hadis Melayu pertama, fikih Melayu Pertama, dan sebagainya. ${ }^{11}$ Hal ini menunjukan bahwa naskahnaskah tersebut merupakan sumber primer dalam mempelajari Islam di Indonesia dan bahkan Asia Tenggara (Nusantara).

\footnotetext{
11 Wawancara Oman Fathurrahman dengan Ali Ridho dari Republika. Dimuat di Harian Republika pada tanggal 18 Januari 2010. Hasil wawancara ini juga dimuat di situs: http://arkeologi.we.id/
} 


\section{Peran Perpustakaan dalam Melestarikan Naskah Nusantara}

Perpustakaan pada hakekatnya merupakan suatu lembaga yang menyimpan berbagai informasi yang terdapat dalam berbagai jenis bahan pustaka, baik dalam bentuk tercetak, terekam maupun terpasang yang dikelola secara sistematis. Tujuan utamanya memberikan layanan informasi kepada penggunanya. ${ }^{12}$ Dari pengertian tersebut kita dapat memahami bahwa perpustakaan bukanlah menara gading yang tak tersentuh, namun sebaliknya perpustakaan merupakan menara mercusuar yang harus menerangi seluruh penggunanya agar tidak terlunta-lunta dalam mencari informasi yang dibutuhkannya.

Perpustakaan terdiri dari beberapa jenis. Di antaranya adalah perpustakaan nasional Republik Indonesia (RI), perpustakaan daerah, perpustakaan perguruan tinggi, perpustakaan umum, perpustakaan khusus, perpustakaan sekolah, perpustakaan keliling, perpustakaan lembaga keagamaan, dan taman baca rakyat. Walaupun berbeda jenisnya, sebenarnya tugas dan fungsi inti perpustakaan adalah sama, yaitu untuk menghimpun dan mengumpulkan (to collect), mengolah, memelihara, merawat, dan melestarikan (to preserve), serta memanfaatkan dan melayankan kepada pemakai (to make available). ${ }^{13}$

Mengingat banyaknya kekayaan nilai dan budaya yang terkandung di bumi Nusantara maka pihak yang paling berwenang untuk mengumpulkan (to collect), melestarikan (to preserve), dan menyuguhkan (to make available) kekayaan tersebut adalah perpustakaan nasional RI. Hal ini sesuai dengan

\footnotetext{
${ }^{12}$ Zuflikar Zein, Klasifikasi DDC 22: Buku Kerja, hal.1 (Depok, 2007)

13 Sutarno, NS. Manajemen Perpustakaan: Suatu Pendekatan Praktis, (Jakarta: Sagung Seto, 2006).
}

$\begin{array}{cccr}\text { kewenangan } & \text { yang } & \text { diemban oleh } \\ \text { perpustakaan } & \text { nasional } & \text { beruoa i) } \\ \text { merumuskan } & \text { dan } & \text { melaksanakan }\end{array}$

kebijakan tertentu di bidang perpustakaan dan ii) merumuskan dan melaksanakan kebijakan pelestarian pustaka budaya bangsa dalam mewujudkan koleksi deposit nasional dan pemanfaatannya. ${ }^{14}$

Dalam kaitannya dengan naskah Nusantara yang terdapat di seluruh pelosok negeri, perpustakaan nasional sebagai penyelamat kekayaan intelektual bangsa, pada sekitar bulan Juni tahun 2014 telah berhasil melakukan digitalisasi 3.050 naskah kuna dari 10.500 koleksi yang mereka miliki. Diperkirakan proses digitalisasi ini akan selesai paling lambat lima tahun ke depan, tepatnya 2019. Menurut Kepala Perpustakaan Nasional, Ibu Sri Sularsih, proses digitalisasi ini dilakukan karena mengingat kondisi fisiknya yang tidak mungkin lagi diakses publik dalam bentuk aslinya. Dari sekian banyak naskah yang ada, ada beberapa yang hanya didapat kopiannya saja, karena para pemilik naskah aslinya tidak mau melepas. Bila para pemiliki itu mau melepasnya, perpustakaan nasional bersedia membayar naskah-naskah kuna tersebut. ${ }^{15}$

Namun sayangnya, apabila kita melihat situs resmi perpustakaan nasional, dari ribuan naskah yang telah didigitalisasi tersebut kita baru bisa mengakses 345 naskah, 24 majalah langka, dan 25 buku langka. Hal ini mungkin saja terjadi karena kurangnya sumber daya manusia yang dapat mengakses isi naskah tersebut yang ditulis dalam berbagai bahasa daerah di Indonesia. Alasan lain bisa juga karena terbatasnya kapasitas server dari

\footnotetext{
14

http://kelembagaan.pnri.go.id/beranda/tugas _fungsi_wewenang/

15 Berita dari http://m.antara news.com/berita/439651/sudah-3050naskah-kuna-didigitalisasi-perpustakaannasional. Berita diakses pada tanggal 06 September 2014.
} 
perpustakaan nasional RI yang tidak mungkin menampung semua naskah yang telah digitalisasi tersebut. Hal tersebut, tentu saja harus segera diatasi mengingat bahwa minat dan animo masyarakat terhadap kajian Nusantara cukup tinggi. Kajian-kajian terhadap naskah Nusantara biasanya banyak dilakukan para mahasiswa dan para ahli dalam ranah ilmu budaya, bahasa, sastra dan filologi serta ilmu-ilmu lain yang berkaitan.

Selain itu, ternyata keberadaan naskah kuna di perpustakaan nasional, menurut Irhamni, ${ }^{16}$ dapat menjadi kekuatan bagi perpustakaan nasional RI dalam strategi branding agar dapat menjadi yang terdepan dalam pengelolaan perpustakaan. Sejauh ini usaha perpustakaan nasional dalam melakukan strategi branding ini, telah dilakukan dalam beberapa hal. Pertama, translasi dan transliterasi naskah kuna. Upaya penerjamahan naskah ini perlu dilakukan agar mempermudah menyebarkan isi naskah dan koleksi langka Nusantara. Kedua, Promosi dan pameran. Hal ini sangat perlu dilakukan untuk memperkenalkan khasanah budaya Nusantara serta menarik minat masyarakat internasional untuk datang dan meneliti naskah kuna di perpustakan nasional RI. Ketiga, kerjasama dengan peneliti Asing. Perpustakaan nasional RI telah banyak melakukan kerjasama dengan beberapa peneliti asing dari negara Belanda, Australia, Amerika, dan negara lainnya. Keempat, promosi melalui lembaga internasional. Perpustakaan nasional RI juga telah melakukan promosi naskah kuna melalui lembaga PBB yaitu UNESCO. Salah satu naskah yang dipromosikan adalah naskah Negara Kertagama yang berhasil

16 Irhamni adalah salah seorang staf Perpustakaan Nasional RI yang bertugas di bagian Biro Hukum dan Perencanaan Perpustakaan Nasional RI. mendapatkan predikat sebagai memory of the world. ${ }^{17}$

Namun, tentu saja upaya-upaya branding yang dilakukan oleh perpustakaan nasional itu juga menghadapi beberapa hambatan. Pertama, Naskah kuna di Indonesia tersebar di seluruh pelosok negeri. Hal ini menyebabkan sulitnya mengakumulasi naskah kuna, sehingga perlu sekali membuat tim khusus untuk berburu naskah tersebut. Kedua, sulitnya menemukan penutur asli bahasa naskah. Hal ini terjadi karena di Indonesia terdapat lebih dari 746 bahasa. Ketiga, kebijakan pembelian atau perolehan naskah yang masih bersifat birokratis dan kurang fleksibel. ${ }^{18}$

\section{Peran Perpustakaan Perguruan Tinggi Islam}

Mengingat banyaknya naskah yang dimiliki oleh bumi pertiwi kita, maka tidaklah mungkin perpustakaan nasional melakukan pekerjaan berat itu sendirian. Perpustakaan-perpustakaan lain yang posisinya dekat dengan kantong-kantong Nusantara juga harus turun tangan demi menyelematkan kekayaan bangsa yang tak ternilai tersebut. Bila perpustakaan nasional RI bertugas untuk mengkoleksi dan melakukan deposit terhadap seluruh jenis naskah Nusantara, maka perpustakaan perguruan tinggi Islam memiliki fungsi yang lebih spesifik yaitu untuk menghimpun dan melestarikan naskah-naskah Nusantara yang berada di wilayah sekitarnya, terutama yang memiliki tema-tema keIslaman.

\footnotetext{
17 Hal ini disampaikan oleh Irhamni dalam artikelnya yang berjudul: "Strategi Perpustakaan Nasional Melakukan Branding Melalui Naskah Kuna dan Koleksi Langka.” Artikel tersebut diupload di situs http://academia.edu.

${ }^{18}$ Irhamni . "Strategi Perpustakaan Nasional Melakukan Branding Melalui Naskah Kuna dan Koleksi Langka." http://academia.edu.
} 
Salah satu fungsi penting perpustakaan perguruan tinggi Islam adalah untuk mempromosikan naskah-naskah Nusantara tersebut kepada seluruh stake holdernya. Jangan sampai naskah-naskah tersebut hanya ada di tangan para pemilik, di laptop para peneliti dan hard disknya para ahli. Keberadaan naskah tersebut tentu sangat penting untuk para mahasiswa dan seluruh civitas akademika. Para mahasiswa sebagai calon-calon intelektual di masa depan, perlu mengetahui tentang sejarah dan jati diri bangsanya di masa lampau agar mereka tidak lupa dengan identitas mereka sebelumnya. Begitu juga Masyarakat luas perlu mengetahui lebih jauh tentang naskah-naskah tersebut.

Sebagai perbandingan, bila kita melihat situs-situs perpustakaan tinggi luar negeri, maka kita dapat dengan mudah melihat kataog buku langka (rare book) dan naskah kuna (manuscript). Misalnya di situs Harvard Libray terdapat koleksi arsip berjudul "Rev. Calude L. Picken, Jr. Collection on Muslim in China, 18581984" yang berisi surat-menyurat, tulisan diary, biografi tentang Cina Muslim dan beberapa photo. ${ }^{19}$ Perpustakaan Universitas Cambridge juga memiliki naskah berjudul "wonders of creation" tulisan Zakariya ibn Muhammad yang ditulis pada tahun 974 Hijriah, dalam salah satu karya koleksi khususnya. ${ }^{20}$ Sementara itu di perpustakaan Australian National University (ANU) terdapat 20 naskah Bali, yang diberi judul katalog "Balinese Manuscript Collection Index". ${ }^{21}$ Contoh-contoh manuskrip tadi mungkin hanya bagian-bagian kecil dari koleksi naskah yang mereka miliki.

19

http://hollis.harvard.edu/?q=subjetcs:22man ${ }_{20} \underline{\text { uscrip22 }}$

http://www.lib.cam.ac.uk/specialcollections/

${ }^{21}$ http://anulib.anu.edu.au/subjects/asiapacific/balinese-manuscript-collectioninddex/index.html
Fenomena yang jauh berbeda sangat terlihat di perpustakaan-perpustakaan perguruan tinggi Islam kita. Kalau kita mengamati secara mendalam di beberapa situs perpustakaan PTAIN, kebanyakan perpustakaan PTAIN baru beranjak untuk melakukan penguatan koleksi dan sistem otomasi. Penguatan koleksi itu dilakukan dengan memperkaya buku-buku yang sesuai dengan kurikulum, berlangganan jurnal online, dan penguatan sistem repositori guna mendongkrak posisi mereka di Webometric. Sistem repositori itu sendiri adalah merupakan database karya ilmiah dan penelitian yang dihasilkan oleh civitas akademika dimana perpustakaan perguruan tinggi itu berada. Dalam hal penguatan sistem otomasi dan teknologi informasi, ada beberapa perpustakaan PTAIN yang sudah beralih dari sistem barcode ke sistem RFID, seperti perpustakaan UIN Riau dan UIN Yogyakarta. Namun wilayah penguatan koleksi buku langka dan naskah kuna belum begitu banyak tersentuh, kecuali dalam penelitian para mahasiswanya.

\section{Geliat Semangat di Fakultas Adab dan Humaniora}

Berbicara tentang naskah Islam Nusantara, ada perkembangan yang cukup menggembirakan di Fakultas Adab dan Humaniora (FAH) UIN Syarif Hidayatullah Jakarta. Di Bawah pimpinan dekan yang baru, yaitu Prof. Dr. Oman fathurrahman, sekaligus sebagai Begawan fililogi Islam Indonesia, FAH berniat menjadi "e-Faculty Berbasis riset dan berkarakter Islam Nusantara", seperti yang tertera dalam visi FAH UIN Jakarta. $^{22}$ Visi itu kemudian dituangkan dalam beberapa misi berikut ini:

1. Menyelenggarakan pendidikan, riset, dan publikasi bermutu di bidang ${ }^{22}$ http://fah.uinjkt.ac.id/index.php/profil/visi-
misifah 
ilmu humaniora untuk meningkatkan kemajuan dan peradaban masyarakat, serta mengintegrasikan teori dan metodologi keilmuwan dengan Islam, kemanusian, dan keindonesiaan.

2. Menyelenggarakan pengelolaan fakultas secara amanah, professional, modern, dan akuntabel (good faculty governance);

3. Meningkatkan kesejahteraan tenaga pendidik dan kependidikan atas dasar kerja secara proporsional.

Visi misi tersebut akan dilaksanakan semaksimal mungkin agar tujuan-tujuan dari keberadaan FAH UIN Jakarta dapat mencapai tujuan yang telah ditetapkan. Salah satu tujuan besar dari FAH adalah menghasilkan lulusan yang memiliki pengetahuan luas di bidang ilmu Humaniora, memiliki keterampilan berbahasa Arab dan Inggris yang komunikatif, serta mampu melakukan penelitian berbasis sumber-sumber primer Islam Nusantara.

Demi tercapainya tujuan tersebut, FAH telah melakukan beberapa langkah yang signifikan. Diantaranya adalah dengan membuat 2 kelas internasional di program studi Bahasa dan Sastra Inggris (BSI) dan Bahasa dan Sastra Arab (BSA). Mahasiswa di kelas internasional tersebut diseleksi dari semua mahasiswa yang diterima di program studi BSI dan BSA. Selain itu FAH, sekarang juga sudah mempersiapkan adanya Pusat Database Sumber Primer Islam Nusantara.

\section{Pusat Database Sumber Primer Islam Nusantara}

Pada awalnya Database ini diberi nama Thesaurus of Indonesian Islamic Manuscript $^{23}$. Database ini merupakan hasil kerjasama antara Puslitbang LEKTUR, Kementrian Agama Republik

\footnotetext{
${ }^{23}$ Database ini masih dapat dilihat di situs: http://tiim.ppim.or.id/.
}

Indonesia dengan Pusat Pengkajian Islam dan Masyarakat (PPIM) UIN Syarif Hidayatullah Jakarta. Database ini merupakan sejenis direktori yang memberikan petunjuk tentang sumbersumber dari naskah Islam Nusantara dan penelitian-penelitian terhadap naskah tersebut yang ada di seluruh pelosok negeri. Sejauh ini dalam database tersebut telah terkumpul 3.026 entri. Setelah kerja sama dengan Kementrian Agama RI berakhir, database akan diserahkan kepada tim dari FAH UIN Jakarta agar penambahan entri-entri baru dapat segera dilaksanakan. ${ }^{24}$

Database inilah kemudian yang akan menjadi cikal bakal berkembangnya FAH UIN Jakarta menjadi sebuah e-faculty yang berbasis riset dan berkarakter Islam Nusantara. Orang-orang yang terlibat dalam pembentukan database memiliki latar belakang berbeda. Ada yang memiliki latar belakang, sejarah, bahasa Arab, Teknik Informatika, filologi dan ilmu perpustakaan. Database akan selalu diupdate setiap tahunnya, karena diperkirakan bahwa penelitian tentang naskah akan terus menerus bertambah. Sejalan dengan banyaknya penelitian tentang naskah, maka kemungkinan akan ditemukannya naskah yang baru sangat besar sekali. Pada pertengahan Oktober 2014, Database ini siap diluncurkan bersamaan dengan acara Festival Budaya Islam Nusantara di FAH UIN Jakarta.

Di kemudian hari, para mahasiswa, para ahli dan peneliti baik dari dalam maupun luar negeri diharapkan akan menjadikan database ini sebagai media untuk menelusuri sumber-sumber primer di seluruh Indonesia. Sehingga pada akhirnya akan banyak bermuncul penelitian-penelitian tentang naskah dan ilmu-ilmu yang berkaitan setelah

\footnotetext{
${ }^{24}$ Disampaikan oleh Oman Fathurahman saat rapat pembentukan tim Database Sumber Primer Islam Nusantara, Senin 08 September 2014.
} 
mengakses database ini terlebih dahulu. Lama kelamaan FAH UIN Jakarta akan dikenal di kawasan lokal, nasional, regional dan internasional sebagai Fakultas Adab dan Humaniora yang memiliki distingsi dalam kajiannya tentang Islam Nusantara. Iniliah Brand Image yang menjadi cita-cita FAH di masa depan nanti.

Database ini nantinya direncanakan akan diintegrasikan dengan sistem otomasi di perpustakaan FAH. Sebagai tindak lanjut dari rencana besar FAH ini, perpustakaan FAH juga telah mengalami renovasi besar-besaran. Setelah dilakukan weeding (penyiangan) terhadap koleksi-koleksi yang sudah tidak terpakai lagi, seluruh database koleksi yang ada di perpustakaan FAH juga akan dimigrasi pada sistem yang dapat berintegrasi dengan sistem otomasi di perpustakaan utama UIN Syarif Hidayatullah Jakarta. Selain itu, yang lebih penting lagi, sistem otomasi di perpustakaan FAH ini harus dapat diakses di situs FAH agar database sumber primer Islam Nusantara tersebut dapat diakses secara online.

Mengingat pentingnya manfaat Database Sumber Primer Islam Nusantara ini sebagai brand dari FAH UIN Jakarta, maka perpustakaan FAH melalui para pustakawannya harus dapat memahami lebih jauh lagi tentang fungsi internet dan teknologi informasi. Setelah munculnya internet, maka fungsi pustakawan bukanlah hanya mengelola dan menyebarkan informasi dari media-media tercetak, namun juga sumber-sumber informasi lain yang banyak bertebaran di dunia maya. Menurut K.Nageswara dan KH Babu ada beberapa peranan baru pustakawan di era internet dan World Wide Web, peranan tersebut adalah sebagai berikut:

1. Pustakawan Sebagai Mediator
Pencarian

Pustakawan harus benar-benar menguasai dan mengetahui kuantitas maupun kualitas koleksinya di perpustakaan. Baik yang tercetak maupun digital. Begitu juga dengan sumber-sumber informasi di internet agar dapat membantu menelusuri informasi yang dibutuhkan para pengguna.

\section{Pustakawan Sebagai Fasilitator}

Fasilitator dalam konteks ini adalah pustakawan harus mampu menguasi berbagai gadget yang memungkinkan untuk mencari berbagai informasi berbayar maupun tidak berbayar di dunia maya. Pustakawan harus dapat mengetahui tata cara berlangganan dan mengakses jurnal-jurnal online berbayar.

3. Pustakawan Sebagai Pelatih Pengguna

Dalam hal ini pustakawan berperan sebagai mentor yang membimbing para pengguna agar dapat mengakses berbagai sumber informasi di perpustakaan dan dunia maya.

\section{Pustakawan Sebagai Peneliti}

Kalau perpustakaaan sudah dapat dengan mudah mengetahui dan mengakses sumber-sumber informasi di perpustakaan dan internet, maka ia juga dapat dengan mudah melakukan penelitian dengan berlandaskan sumbersumber informasi tersebut.

\section{Pustakawan sebagai Desainer interface}

Bila pustakawan sudah dapat memiliki keterampilan dalam teknologi informasi dan internet, maka seorang pustakwan dapat dengan mudah menjadi desainer bagi rupa situs perpustakaan yang dimiliki agar dapat menyesuaikan diri dengan kebutuhan pengguna.
6. Pustakawan
Sebagai
Manajer
Pengetahuan 


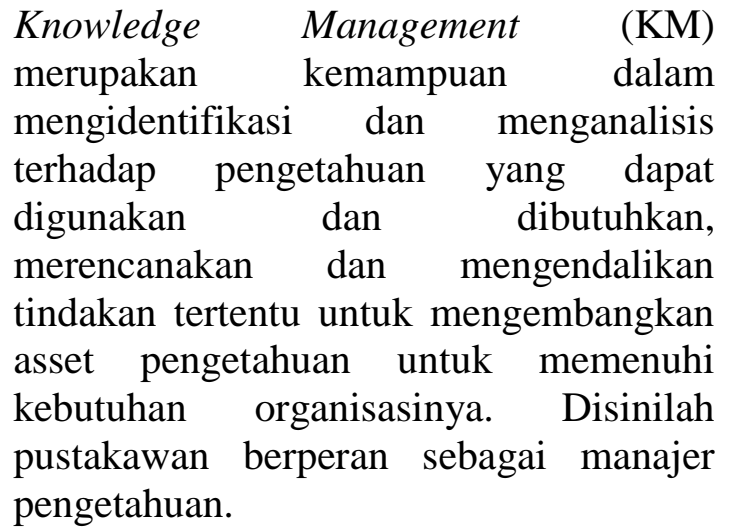

7. Pustakawan Sebagai Penyaring Informasi

Tidak semua informasi yang ada di perpustakaan maupun di internet cocok dengan kebutuhan pengguna, tugas pustakawanlah untuk melakukan seleksi dan penyaringan terhadap informasiinformasi tersebut. $^{25}$

Karena database ini kemudian akan diintegrasi dalam situs FAH dan perpustakaan $\mathrm{FAH}$, pustakawan harus mengakrabkan diri dengan internet. Pustakawan tidak bisa lagi gaptek dengan teknologi. Peranan pustakawan seperti yang disebutkan di atas harus bisa dilaksanakan dengan baik. Selain itu dengan keterampilan berselancar di dunia maya ini, bukan tidak mungkin pula pustakawan menemukan informasi tentang naskah dan kekayaan lain yang berkaitan dengan Islam Nusantara.

Namun kalau melihat sumber daya manusia di perpustakaan FAH, hal ini agak sedikit menghawatirkan, karena jumlahnya yang sangat terbatas. Di perpustakaan FAH sejauh ini hanya ada dua orang staf perpustakaan, dan dua orang office boy yang bertugas membantu di bagian sirkulasi. Untuk mengatasi hal ini Mukmin Suprayogi dalam artikelnya menyatakan bahwa wacana pengiriman

\footnotetext{
${ }^{25}$ K. Nageswara Rao dan KH Babu, Role of I Librarian in internet and world wide web environment, Informing Sicence, volume 4 , no 1,2001 , h. 30-32
}

mahasiswa program studi ilmu perpustakaan untuk membantu pengembangan perpustakaan FAH adalah cara yang terbaik. ${ }^{26}$ Keberadaan jurusan Ilmu Perpustakaan di FAH dapat dikatakan merupakan peluang besar untuk menghadapi hambatan ini. Jurusan Ilmu Perpustakaan yang bertugas menghasilkan pustakwan-pustakawan yang handal, dapat memberdayakan dosen dan mahasiswanya untuk mengembangkan perpustakaan FAH dengan cita-cita bersama yaitu mewujudkan fakultas dengan brand Islam Nusantara.

Dalam kaitannya dengan pelestarian naskah Islam nusanatara, jurusan Ilmu perpustakaan sebagai pencetak calon pustakawan dan pegiat dunia informasi di negeri ini, sudah seharusnya mengenalkan dan membekali para mahasiswanya tentang naskah dan kemampuan melestarikannya.Upaya ini dapat dilaksanakan dengan memperdalam beberapa mata kuliah yang berkaitan dengan naskah, misalnya pelestarian bahan pustaka dan filologi. Dalam satuan acara pelajaran (SAP) mata kuliah-mata kuliah tersebut bisa saja ditekankan kompetensi-kompetensi berikut ini:

1. Mengetahui bahan dasar dari naskah bagaimana sifat bahan tersebut dan bagaimana cara mengawetkannya.

2. Memiliki Kemampuan menggandakan naskah tersebut dengan cara melakukan digitalisasi komputer 3. Mengetahui isi naskah tersebut agar dapat melakukan deskripsi bibliografi dan katalogisasi

4. Memahami aksara dan bahasa naskah yang biasanya tertulis dalam huruf pegon (arab jawa), huruf jawi (arab

\footnotetext{
${ }^{26}$ Mukmin Suprayogi. Potret Perpustakaan Fakultas Adab dan Humaniora UIN Syarif Hidayatullah Jakarta. Al-Maktabah: Jurnal Komunikasi dan Informasi Perpustakaan, Vol . 12, 12 Desember 2013. Hal 79 - 93.
} 
melayu), huruf arab sunda, dan hurufhuruf lainnya

5. Menguasai teknologi informasi dan internet untuk memperkaya dan mempromosikan naskah Islam Nusantara

\section{Promosi Database Sumber Primer Islam Nusantara}

Ketika database ini kemudian menjadi bagian dari koleksi yang dimiliki perpustakaan $\mathrm{FAH}$, maka perpustakaan berkewajiban untuk mempromosikannya. Promosi perpustakaan sangat perlu dilakukan agar koleksi dan seluruh aktifitas perpustakaan yang berhubungan dengan jasa perpustakaan dapat diketahui dan dimanfaatkan secara maksimal oleh seluruh pengguna. Menurut Wiratningsih promosi perpustakaan merupakan salah satu dari komponen pemasaran. Dengan mempromosikan kelembagaan, koleksi, sistem dan jenis pelayanan perpustakaan, maka terjadilah proses pendekatan informasi kepada pengguna. Pengguna akan mengetahui koleksi apa yang ada dan pelayanan apa saja yang tersedia. Sedangkan pengguna yang belum tahu atau sudah tahu namun belum pernah memanfaatkan jasa layanan akan mengenal lebih jauh dan kemudian tertarik untuk datang atau memanfaatkan, sehingga pengunjung bertambah, koleksi dan jasa perpustakaan termanfaatkan. Intinya promosi perpustakaan dapat dikatakan sebagai upaya mengenalkan koleksi dan seluruh aktivitas perpustakaan agar diketahui khalayak ramai, sehingga terjadi pertukaran informasi perpustakaan dan para penggunanya. ${ }^{27}$

Bentuk promosi perpustakaan, menurut Rahardjo dapat dilakukan melalui publisitas, iklan, kontak perorangan,

\footnotetext{
${ }^{27}$ Riah Wiratningsih. Promosi Perpustakaan why not?.

http://riah.staff.uns.ac.id/2009/02/11/ promosi-perpustakaan-why-not/. Diakses tanggal 07 September 2014
}

insentif, suasana dan lingkungan perpustakaan, dan program khusus perpustakaan. ${ }^{28}$ Publisitas adalah salah satu alat promosi yang ampuh dan murah untuk memperkenalkan perpustakaan. Publisitas ini dapat dilakukan melalui press release dalam rangka pembukaan ataupun acara penutupan pameran, lomba dan acara lainnya. Hal penting yang harus diperhatikan dalam publisitas ini adalah perpustakaan harus dapat menjalin hubungan baik dengan media masssa. Bentuk publisitas tentang adanya Database Sumber Primer Islam Nusantara di FAH ini, dapat dilakukan dengan mempromosikannya dalam setiap acara seminar, workshop, pelatihan, pameran dan acara lain di lingkungan UIN Jakarta maupun tempat yang memungkinkan. Adalah sebuah kabar menggembirakan bahwa rencananya Database Sumber Primer Islam Nusantara ini akan dilaunching secara masif pada pertengahan Oktober 2014 dalam acara pameran Festival Budaya Islam Nusantara.

Iklan memiliki sedikit perbedaan dengan publisitas. Bila publisitas dapat dilakuan secara cuman-cuma, iklan sebaliknya memerlukan biaya yang cukup besar. Iklan dapat disampaikan dalam bentuk media cetak seperti surat edaran, brosur, bulletin poster ataupun papan pengumuman. Media massa baik dalam bentuk cetak maupun elektronik juga merupakan media yang ampuh jika dilakukan sesuai dengan pesan yang diinginkan. Dalam kaitannya dengan promosi lewat iklan, tim Database ini bisa bekerjasama dengan admin situs UIN Jakarta, Pustipanda, dan Tabloid Institut milik mahasiswa. Tim juga bisa

\footnotetext{
${ }^{28}$ Arllinah Imam Rahardjo. Mengembangkan Program Promosi Serta Gemar Membaca di Perpustakaan. http://faculty.petra.ac.id/arlinah/perpustaka an/PROMOSI/promosi99.pdf diakses tanggal 08 September 2014.
} 
bekerjasama dengan media cetak maupun elektronik yang dapat ditemui di wilayah Jakarta.

Kontak perorangan merupakan bentuk yang paling ampuh diantara bentukbentuk promosi yang lain karena dapat meningkat hubungan staf perpustakaan dan pengguna. Perpustakaan dapat mengetahui lebih jauh apa kebutuhan, keinginan dan minat para pemustaka. Untuk promosi Database Sumber Primer Islam Nusantara, hal ini mungkin sangat mudah dilakukan, perpustakaan atau tiam Database hanya tinggal meminta para dosen dan mahasiswa untuk sering menyampaikan keberadaannyai di kelas maupun di semua tempat yang merek kunjungi.

Insentif secara sederhana dapat diartikan sebagai pemberian uang, barang atau sikap yang dimaksudkan untuk mendorng perubahan sikap konsumber. Termasuk dalam insentif ini adalah pemberian penghargaan atau hadiah pada peminjam terbanyak, wawancara khusus bagi pengguna aktif, publikasi karya pengguna dalam media (situs fakultas) ataupun jasa penelusuran gratis. Dalam konteks ini Perpustakaan FAH bisa saja memberikan penghargaan bagi mereka yang secara intensif berkunjung, meminjam koleksi dan menggunakan pangkalan Data base ini. Hal ini dilakukan untuk memacu mereka dalam memanfaatkan koleksi secara maksimal dan melakukan penelitian-penelitian yang inovatif.

Suasana dan lingkungan perpustakaan secara tidak langsung merupakan promosi bagi perpustakaan itu sendiri. Sehingga istilah produk yang baik itu mempromosikan dirinya sendiri adalah benar adanya. Secanggih dan selengkap apapun perpustakaan, bila ruangannya gelap, pengap, kotor dan semrawut pasti tak akan dikunjungi oleh para penggunanya. Dalam kaitannya dengan perpustakaan FAH hal ini sekarang sedang dalam proses on going, sehingga suatu saat nanti setelah renovasi selesai dilakukan, pengguna dapat lebih nyaman berada di perpustakaan.

Promosi perpustakaan dapat pula dilakukan dengan cara mengadakan program khusus perpustakaan. Program khusus perpustakaan tersebut bisa dalam bentuk "sahabat perpustakaan", program magang perpustakaan, program gemar membaca, aneka lomba, bimbingan pemakai dan sebagainya. Dalam kaitannya dengan promosi Database Sumber Primer Islam Nusantara, perpustakaan FAH bisa saja mengadakan acara "Sahabat Naskah Nusantara", "Berkelana dengan naskah", dan kegiatan-kegiatan lain yang memungkinkan pengguna dapat mengenal lebih jauh tentang khazanah Islam Nusantara.

\section{Penutup}

Mengakhiri tulisan ini, demi mengusung semangat Fakultas Adab dan Humaniora menjadi e-faculty yang berbasis riset dan berkarakter Islam Nusantara, maka seluruh elemen yang ada di dalam FAH harus bekerjasama dan memfokuskan diri pada khazanah Islam Nusantara, salah satunya adalah naskah Islam Nusantara. Perpustakaan FAH harus tumbuh menjadi perpustakaan yang memiliki kemampuan untuk mengumpulkan informasi tentang naskah Islam Nusantara (to collect), merawat dan memeliharanya (to preserve) dan mengemas serta mempromosikan (to make available) informasi tersebut kepada seluruh pemustaka. Bila hal tersebut sudah dapat dilakukan oleh perpustakaan, pustakawan dan seluruh elemen di Fakultas Adab dan Humaniora, maka bukan tidak mungkin bila suatu saat nanti perpustakaan FAH UIN Jakarta juga dapat menjadi "Juri Kunci” Islam Nusantara. 


\section{Daftar Pustaka}

Fathurrahman, Oman (2011). Penguatan Kajian Islam Nusantara. Makalah dalam acara saresehan Lakpesdam PCINU, Kairo Mesir, kamis 21 juli 2011. tersedia di situs, http://oman.uinjkt.ac.id.

Hilmy, Masdar. (2012). Menjadi Islam Indonesia. Harian Kompas. Edisi 24 November 2012.

Irhamni. (2012). Strategi Perpustakaan Nasional Melakukan Branding Melalui Naskah Kuna dan Koleksi Langka." Tersedia

https://academia.edu/6136731/STRATEG

I_PERPUSTAKAAN_NASIONAL_ME

LAKUKAN_BRANDING_MELALUI

NASKAH_KUNA_DAN_BUKU_LANG $\underline{\mathrm{KA}}$

Rahardjo, Arlinah Imam (1999). Mengembangkan Program Promosi Serta Gemar Membaca di Perpustakaan. Tersedia di: http://faculty.petra.ac.id/arlinah/perpustak aan/PROMOSI/promosi99.pdf

Rao, K. Nageswara dan Babu. (2001). $\mathrm{KH}$. Role of Librarian in Internet and World Wide Web Environment. Informing Science, volume 4, No.1. Hal 30-32

Setiawan, Ebta (2014). Kamus Besar Bahasa Indonesia (KBBI), Kamus Versi Online, daring (dalam jaringan), tersedia di: http://kbbi.web.id/naskah

Sutarno, NS.(2006). Manajemen Perpustakaan: Suatu Pendekatan Praktis. Jakarta: Sagung Seto.

Wiratningsih, Riah. (2009). Promosi Perpustakaan why not?. Tersedia di: http://riah.staff.uns.ac.id/2009/02/11/ promosi-perpustakaan-why-not/
Zen, Zulfikar. (2007). Klasifikasi DDC 22: Buku Kerja, Depok: Universitas Indonesia.

\section{Berita}

Oman: Manuskrip Nusantara, Gambarkan Identitas Kultural. Berita di: http://www.gusdur.net/Berita/Detail?id=4 60/hl=id/Oman_Manuskrip_Nusantara_G ambarkan_Identitas_Kultural

Ulama-ulama Indonesia yang Sudah Mendunia", [Syahid/hid/hidayatullah.com], tersedia di http://indonesiaindonesia.com/f/95138ulama-ulama-indonesia-mendunia/

DR. OMAN FATHURAHMAN: Nasib Manuskrip Islam Nusantara Memprihatinkan, berita tersedia di: http//arkeologi.wweb.id/articles/efigrafia-manuskrip/566-dr-oman-fathurahmannasib-manuskrip-Islam-Nusantaramemprihatinkan

Sudah 3.050 naskah kuno didigitalisasi Perpustakaan Nasionl, berita tersedia di: http://m.antaranews.com/berita/439651/s udah-3050-naskah-kuna-didigitalisasiperpustakaan-nasional

http://kelembagaan.pnri.go.id/beranda/tug as_fungsi_wewenang/

http://hollis.harvard.edu/?q=subjetcs: $22 \mathrm{~m}$ anuscrip22

http://www.lib.cam.ac.uk/specialcollectio $\underline{\mathrm{ns} /}$

http://anulib.anu.edu.au/subjects/asiapacific/balinese-manuscript-collectioninddex/index.html

http://fah.uinjkt.ac.id/index.php/profil/vis i-misifah 